\title{
Oceanicola nanhaiensis sp. nov., isolated from sediments of the South China Sea
}

\author{
Jun Gu, ${ }^{1}$ Bin Guo, ${ }^{1}$ Ya-Nan Wang, ${ }^{1}$ Su-Lin Yu, ${ }^{1}$ Ryuhei Inamori, ${ }^{2}$ Ri Qu, ${ }^{1}$ \\ Yu-Guang $\mathrm{Ye}^{3}$ and Xiao-Lei $\mathrm{Wu}^{1}$ \\ ${ }^{1}$ Department of Environmental Science and Engineering, Tsinghua University, Beijing 100084, \\ People's Republic of China \\ ${ }^{2}$ Graduate School of Life and Environmental Sciences, Tsukuba University, 1-1-1, Tennodai, \\ Tsukuba 305-8572, Japan \\ ${ }^{3}$ Qingdao Institute of Marine Geology, Qingdao 266071, People's Republic of China
}

Correspondence

Xiao-Lei Wu

xiaolei_wu@tsinghua.edu.cn
The genus Oceanicola, belonging to the order Rhodobacterales of the Alphaproteobacteria, was proposed by Cho \& Giovannoni (2004). The genus currently includes two species, Oceanicola granulosus (the type species) and Oceanicola batsensis, which are Gram-negative, nonmotile, poly- $\beta$-hydroxybutyrate-accumulating, contain large amounts of unsaturated cellular fatty acids and have DNA G $+C$ contents of 71.5 and $67.3 \mathrm{~mol} \%$, respectively. In this study, we isolated a novel strain, strain SS011B1-20 ${ }^{\mathrm{T}}$, from sediments of the South China Sea, and found that it was phylogenetically related to members of the genus Oceanicola. We describe the characterization and classification of strain SS011B1-20 ${ }^{\mathrm{T}}$ using polyphasic methods.

Strain SS011B1-20 ${ }^{\mathrm{T}}$ was isolated from sediments of the South China Sea (collected at a depth of $1100 \mathrm{~m}$ ) using a 10fold dilution plating technique on marine agar 2216 (MA; Nakamura \& Silver, 1994) and was purified by restreaking on MA plates incubated at $30^{\circ} \mathrm{C}$ for $3-5$ days. When grown to the exponential phase on MA, the cell morphology and flagellum type were examined using transmission and scanning electron microscopy. To determine the assimilation

The GenBank/EMBL/DDBJ accession number for the 16S rRNA gene sequence of strain SS011B1-20 ${ }^{\top}$ is DQ 414420 .

Electron micrographs of cells of strain SS011B1-20 ${ }^{\top}$ are available as supplementary material in IJSEM Online. of carbon sources by strain SS011B $1-20^{\mathrm{T}}$, the mineral medium solution of Shivaji et al. (2005) was used

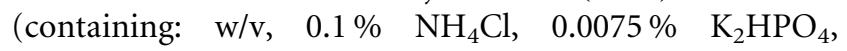
$0.145 \% \mathrm{CaCl}_{2}, 3.0 \% \mathrm{NaCl}, 0.615 \% \mathrm{MgCl}_{2}, 0.075 \% \mathrm{KCl}$ and $0.0028 \% \mathrm{FeSO}_{4}$ ). Different filter-sterilized carbon sources were added at a concentration of $0.2 \%(\mathrm{w} / \mathrm{v})$ after the mineral base solution had been autoclaved. Growth was examined after incubation at $30^{\circ} \mathrm{C}$ for $1,7,10$ and 14 days. The hydrolysis of starch, gelatin and Tween 80 was assessed as described by Smibert \& Krieg (1994). Tests for nitrate and nitrite reduction were performed as described by Lanyi (1987). The optimum $\mathrm{pH}$, temperature and salt concentration for growth were tested using marine broth 2216 . Sensitivity to various antibiotics was tested by using the disc diffusion (Kirby-Bauer) method.

Cellular fatty acid methyl esters were prepared and analysed using gas chromatography according to the instructions of the Microbial Identification System (MIDI). Fatty acid profiles were analysed using the Sherlock system (Microbial ID). Isoprenoid quinones were extracted from fresh cells with methyl chloride/methanol $(2: 1, \mathrm{v} / \mathrm{v})$ and analysed by reversed-phase HPLC (Shim-pack, VP-ODS; Shimadzu).

Genomic DNA was extracted and purified by using the method of Marmur (1961). The DNA G $+C$ content was determined by thermal denaturation (Marmur \& Doty, 
1962), using DNA from Escherichia coli K-12 as a control. The 16S rRNA gene was amplified using the bacterial universal primer pair 8f (5'-AGAGTTTGATCCTGGCTCAG- $3^{\prime}$ ) and 1492r (5'-GGTTACCTTGTTACGACTT- $\left.3^{\prime}\right)$ (Lane, 1991); multiple alignments of the almost-complete 16S rRNA gene sequence were performed with the CLUSTAL_X program (version 1.64b; Thompson et al., 1997). A phylogenetic tree was reconstructed using the neighbour-joining method (Saitou \& Nei, 1987) and was evaluated by bootstrap analysis (based on 1000 resampling replicates) with the programs SEQBOOT, DNADIST, NEIGHBOR and CONSENSE of the PHYLIP package, version 3.6 (Felsenstein, 2004).

The cells of strain SS011B1- $20^{\mathrm{T}}$ were found to be Gramnegative, having the morphology typical of such microorganisms, i.e. possessing an outer membrane, being non-motile, and comprising short rods $(0.7-0.9 \times$ $0.4-0.6 \mu \mathrm{m})$ that divide by binary fission. Neither flagella nor endospores were observed under transmission and scanning electron microscopy (see Supplementary Fig. S1 available in IJSEM Online). Small yellowish colonies (about $1 \mathrm{~mm}$ in diameter) were produced on MA agar after incubation at $30^{\circ} \mathrm{C}$ for $3-5$ days. The colonies were smooth, uniformly circular, convex and opaque. The $\mathrm{pH}$ for growth was 6.0-9.5 (optimum, $\mathrm{pH} 7.5-8.0$ ) and the $\mathrm{NaCl}$ concentrations for growth were $0-10 \%(\mathrm{w} / \mathrm{v})$ (optimum, $2-3 \%)$. Growth was observed at $10-37^{\circ} \mathrm{C}$, but not at 4 or $40^{\circ} \mathrm{C}$. The isolate was positive for oxidase activity and Tween 80 hydrolysis, and weakly positive for nitrate reduction and catalase activity. Tests for gelatin liquefaction, starch hydrolysis, nitrite-reduction activity and urease activity all gave negative results. The main characteristics that differentiate strain SS011B1-20 ${ }^{\mathrm{T}}$ from the two Oceanicola species are listed in Table 1.

Analysis of the almost-complete 16S rRNA gene sequence (1427 bp) revealed that strain SS011B1-20 ${ }^{\mathrm{T}}$ is a member of the Alphaproteobacteria and has a close phylogenetic relationship with the species of the genus Oceanicola (Fig. 1). The topology of the phylogenetic tree and the bootstrap values supported the proposed relationship between strain SS011B1-20 and the species of the genus Oceanicola. The 16S rRNA gene sequence of strain SS011B1$20^{\mathrm{T}}$ showed 96.3 and $94.9 \%$ similarity to those of $\mathrm{O}$. batsensis and O. granulosus, respectively. In general, a $16 \mathrm{~S}$ rRNA gene sequence divergence greater than $2 \%$ is accepted as a criterion for delineating different species (Stackebrandt \& Goebel, 1994). The 16S rRNA gene sequence divergences between strain SS011B1-20 $0^{\mathrm{T}}$ and the recognized species $O$. batsensis and O. granulosus were 3.7 and $5.1 \%$, respectively, and thus the data support the view that strain SS011B1-20 represents a novel species.

The results of the chemotaxonomic analysis are given in Table 2. The main cellular fatty acids of strain SS011B1-20 were $\mathrm{C}_{18: 1} \omega 7 c(81.2 \%), \mathrm{C}_{16: 0}(7.0 \%)$ and $\mathrm{C}_{18: 1}$ methyl $(4.3 \%)$, while those of O. batsensis HTCC $2597^{\mathrm{T}}$ and $O$. granulosus HTCC $2516^{\mathrm{T}}$ were $\mathrm{C}_{18: 1} \omega 7 c$ (31 and $62.8 \%$,
Table 1. Characteristics that differentiate Oceanicola nanhaiensis sp. nov. strain SS011B1-20 from related species of the genus Oceanicola

Strains: 1, SS011B1-20 ${ }^{\mathrm{T}}$; 2, O. batsensis HTCC $2597^{\mathrm{T}}$; 3, O. granulosus HTCC2516 ${ }^{\mathrm{T}}$. Data are from this study and Cho \& Giovannoni (2004). All strains are negative for motility, gelatin hydrolysis and utilization of L-isoleucine, D-raffinose, L-proline, Lrhamnose, L-lysine, D-melibiose and D-xylose. All strains are positive for oxidase activity and utilization of gluconic acid. +, Positive; -, negative; w, weak reaction; ND, not determined.

\begin{tabular}{|c|c|c|c|}
\hline Characteristic & 1 & 2 & 3 \\
\hline DNA G $+\mathrm{C}$ content $(\mathrm{mol} \%)$ & 64.7 & 67.3 & 71.5 \\
\hline Catalase activity & $\mathrm{W}$ & + & - \\
\hline Urease activity & - & + & - \\
\hline Starch hydrolysis & - & ND & ND \\
\hline Nitrate reduction & $\mathrm{W}$ & - & - \\
\hline Minimum growth temp. $\left({ }^{\circ} \mathrm{C}\right)$ & 10 & 4 & 4 \\
\hline Maximum growth temp. $\left({ }^{\circ} \mathrm{C}\right)$ & 37 & 40 & 40 \\
\hline \multicolumn{4}{|l|}{ Susceptibility to: } \\
\hline Chloramphenicol & + & - & + \\
\hline Streptomycin & + & + & - \\
\hline Erythromycin & - & + & + \\
\hline Gentamicin & + & + & - \\
\hline \multicolumn{4}{|c|}{ Utilization of substrates as sole carbon sources } \\
\hline D-Maltose & - & + & + \\
\hline L-Arginine & - & + & + \\
\hline Succinic acid & + & - & - \\
\hline D-Erythrose & - & ND & ND \\
\hline Acetic acid & + & ND & ND \\
\hline L-Sorbose & + & + & - \\
\hline D-Sorbitol & + & - & - \\
\hline Malonic acid & - & + & - \\
\hline Sucrose & + & - & + \\
\hline myo-Inositol & - & + & - \\
\hline D-Trehalose & - & - & + \\
\hline D-Mannitol & + & + & - \\
\hline$\alpha$-D-Lactose & + & ND & ND \\
\hline Pyruvic acid & + & - & + \\
\hline D-Ribose & + & - & + \\
\hline D-Fructose & + & - & - \\
\hline Ethanol & + & - & - \\
\hline Propionic acid & - & + & + \\
\hline Glycine & - & + & - \\
\hline D-Malonic acid & + & + & - \\
\hline D-Cellobiose & + & - & + \\
\hline L-Alanine & - & - & + \\
\hline D-Arabinose & - & + & - \\
\hline D-Glucose & + & - & + \\
\hline Lactic acid & - & + & - \\
\hline L-Glutamic acid & - & + & + \\
\hline Dextrin & + & ND & ND \\
\hline
\end{tabular}

respectively), $\mathrm{C}_{16: 0}\left(15.0\right.$ and $11.9 \%$, respectively) and $\mathrm{C}_{18: 1}$ methyl ( 0 and $8.1 \%$, respectively). The fatty acid $\mathrm{C}_{19: 0}$ cyclo constituted 1.1, 40.4 and $10.8 \%$ in strain SS011B1-20,$O$. 


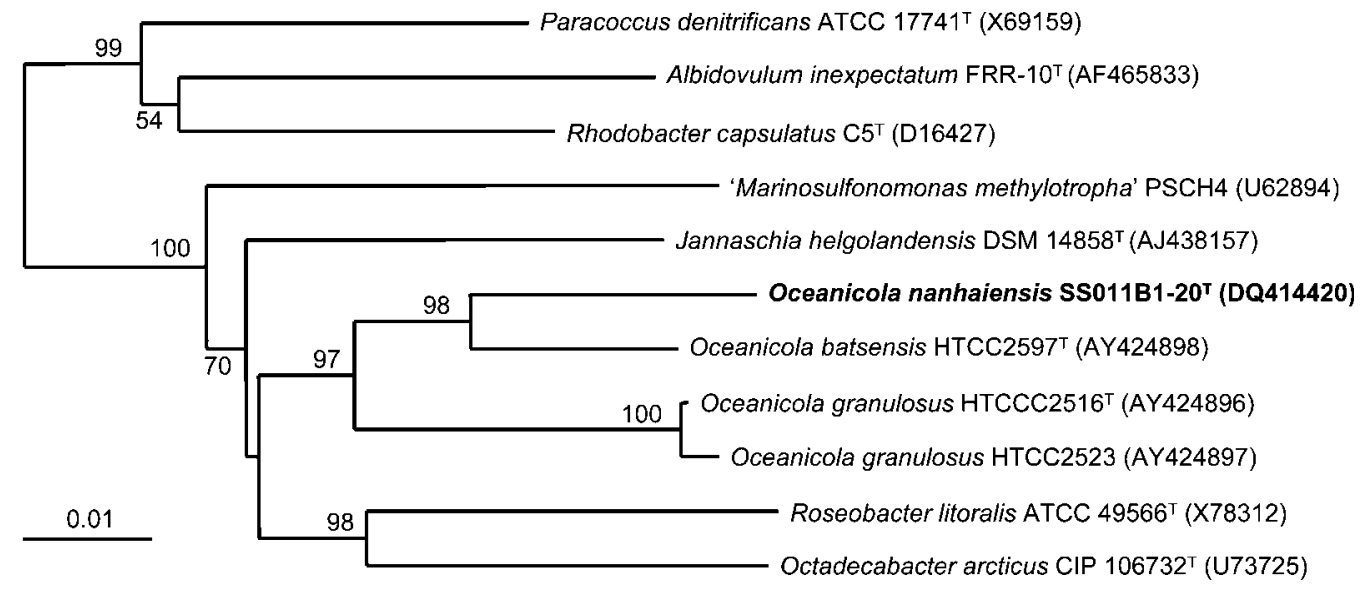

Fig. 1. Neighbour-joining phylogenetic tree for strain SS011B1-20 ${ }^{\top}$, based on $16 \mathrm{~S}$ rRNA gene sequence analysis. Bootstrap values (expressed as percentages of 1000 replications) greater than $50 \%$ are shown at branch points. Bar, 0.01 nucleotide substitutions per nucleotide position.

batsensis and $O$. granulosus, respectively. The major quinone in strain SS011B1-20 ${ }^{\mathrm{T}}$ was Q-10 and the DNA G + C content was $64.7 \mathrm{~mol} \%\left(T_{\mathrm{m}}\right)$.

The above results indicate that strain SS011B1-20 represents a novel marine species within the genus

Table 2. Cellular fatty acid compositions (\%) of strain SS011B $1-20^{\top}$ and related species of the genus Oceanicola

Strains: 1, SS011B1-20 ${ }^{\mathrm{T}}$; 2, O. batsensis HTCC2597 ${ }^{\mathrm{T}}$; 3, O. granulosus HTCC2516 ${ }^{\mathrm{T}}$. Data are from this study and Cho \& Giovannoni (2004).

\begin{tabular}{|lccc|}
\hline Fatty acid & $\mathbf{1}$ & $\mathbf{2}$ & $\mathbf{3}$ \\
\hline $\mathrm{C}_{10: 0} 3-\mathrm{OH}$ & 0.2 & - & 0.1 \\
$\mathrm{C}_{10: 0}$ & 1.0 & 0.4 & 1.5 \\
$\mathrm{C}_{12: 0}$ & 0.1 & 2.0 & - \\
$\mathrm{C}_{12: 0} 3-\mathrm{OH}$ & - & - & 1.6 \\
$\mathrm{C}_{12: 1} \omega 11 c$ & - & 4.9 & - \\
$\mathrm{C}_{14: 0}$ & 0.3 & 1.5 & - \\
$\mathrm{C}_{14: 0} 3-\mathrm{OH}$ & 0.9 & - & - \\
$\mathrm{C}_{15: 0}$ & - & 0.9 & - \\
$\mathrm{C}_{16: 0}$ & 7.0 & 15.0 & 11.9 \\
$\mathrm{C}_{17: 0}$ & 0.4 & 1.5 & 0.4 \\
$\mathrm{C}_{17: 1} \omega 8 c$ & 0.4 & - & 0.3 \\
anteiso- $\mathrm{C}_{17: 0}$ & - & - & 0.2 \\
$\mathrm{C}_{17: 0}$ cyclo & - & - & 0.2 \\
$\mathrm{C}_{18: 0}$ & 1.3 & 2.4 & 0.9 \\
$\mathrm{C}_{18: 1} \omega 7 c$ & 81.2 & 31.0 & 62.8 \\
$\mathrm{C}_{18: 1}$ methyl & 4.3 & - & 8.1 \\
$\mathrm{C}_{19: 0}$ cyclo & 1.1 & 40.4 & 10.8 \\
iso- $\mathrm{C}_{15: 0} 2-\mathrm{OH}+\mathrm{C}_{16: 1} \omega 7 c$ & 1.8 & - & 1.2 \\
Total & 100.0 & 100.0 & 100.0 \\
& & & \\
\hline
\end{tabular}

Oceanicola, for which we propose the name Oceanicola nanhaiensis sp. nov.

\section{Description of Oceanicola nanhaiensis sp. nov.}

Oceanicola nanhaiensis (nan.hai.en'sis. N.L. masc. adj. nanhaiensis pertaining to Nan Hai, the Chinese name for the South China Sea, the source of the sediment from which the type strain was isolated).

Cells are Gram-negative, aerobic, non-spore-forming, nonmotile rods. Small (about 1-2 $\mathrm{mm}$ ) yellowish colonies are produced on MA after incubation at $30^{\circ} \mathrm{C}$ for $3-5$ days. Colonies are smooth, convex and opaque. Growth occurs at $10-37^{\circ} \mathrm{C}$, pH $6.0-9.5$ and $0-10 \% \mathrm{NaCl}$; the optimal growth temperature, $\mathrm{pH}$ and salinity are $28^{\circ} \mathrm{C}, \mathrm{pH} 7.5-8.0$ and $2-3 \% \mathrm{NaCl}$. Positive for oxidase and Tween 80 hydrolysis. Nitrate reduction and catalase activity are weakly positive. Negative for urease activity, denitrification and hydrolysis of starch and gelatin. The utilization of various substrates as sole carbon sources, and other differentiating characteristics, are listed in Table 1. The following substrates are utilized: D-galactose, D-melezitose, succinic acid, acetic acid, L-sorbose, D-sorbitol, sucrose, D-mannitol, $\alpha$-D-lactose, gluconic acid, pyruvic acid, D-ribose, D-fructose, ethanol, D-malonic acid, D-cellobiose, citric acid, D-glucose and dextrin. Sensitive to chloramphenicol, streptomycin and gentamicin. The predominant cellular fatty acid is $\mathrm{C}_{18: 1} \omega 7 c(81.2 \%)$. Fatty acids $\mathrm{C}_{16: 0}(7.0 \%), \mathrm{C}_{18: 1}$ methyl (4.3\%), $\mathrm{C}_{10: 0} 3-\mathrm{OH}(1.0 \%), \mathrm{C}_{18: 0}(1.3 \%)$ and $\mathrm{C}_{19: 0}$ cyclo $(1.1 \%)$ are also present. The predominant isoprenoid quinone is Q-10.

The DNA $\mathrm{G}+\mathrm{C}$ content of the type strain is $64.7 \mathrm{~mol} \%\left(T_{\mathrm{m}}\right)$. The type strain, SS011B1-20 $0^{\mathrm{T}}$ (=LMG $23508^{\mathrm{T}}=$ CGMCC $1.6293^{\mathrm{T}}$ ), was isolated from sediments of the South China Sea, China. 


\section{Acknowledgements}

The authors would like to thank G.-F. Zhao, Z.-Y. Lou, H. Cai and Y.-F. Guo for their valuable help and discussions. This study was supported by the National Natural Science Foundation of China (30300008, 30570033) and the National Basic Research Program of China (2005CB221308).

\section{References}

Cho, J.-C. \& Giovannoni, S. J. (2004). Oceanicola granulosus gen. nov., sp. nov. and Oceanicola batsensis sp. nov., poly- $\beta$-hydroxybutyrate-producing marine bacteria in the order 'Rhodobacterales'. Int J Syst Evol Microbiol 54, 1129-1136.

Felsenstein, J. (2004). PHYLIP (phylogeny inference package), version 3.6. Distributed by the author. Department of Genome Sciences, University of Washington, Seattle, USA.

Lane, D. J. (1991). 16S/23S rRNA sequencing. In Nucleic Acid Techniques in Bacterial Systematics, pp. 115-175. Edited by E. Stackebrandt \& M. Goodfellow. Chichester: Wiley.

Lanyi, B. (1987). Classical and rapid identification methods for medically important bacteria. Methods Microbiol 19, 1-67.

Marmur, J. (1961). A procedure for the isolation of deoxyribonucleic acid from microorganisms. J Mol Biol 3, 208-218.
Marmur, J. \& Doty, P. (1962). Determination of the base composition of deoxyribonucleic acid from its thermal denaturation temperature. J Mol Biol 5, 109-118.

Nakamura, K. \& Silver, S. (1994). Molecular analysis of mercuryresistant Bacillus isolates from sediment of Minamata Bay, Japan. Appl Environ Microbiol 60, 4596-4599.

Saitou, N. \& Nei, M. (1987). The neighbor-joining method: a new method for reconstructing phylogenetic trees. Mol Biol Evol 4, 406-425.

Shivaji, S., Gupta, P., Chaturvedi, P., Suresh, K. \& Delille, D. (2005). Marinobacter maritimus sp. nov., a psychrotolerant strain isolated from sea water off the subantarctic Kerguelen islands. Int J Syst Evol Microbiol 55, 1453-1456.

Smibert, R. M. \& Krieg, N. R. (1994). Phenotypic characterization. In Methods for General and Molecular Bacteriology, pp. 607-654. Edited by P. Gerhardt, R. G. E. Murray, W. A. Wood \& N. R. Krieg. Washington, DC: American Society for Microbiology.

Stackebrandt, E. \& Goebel, B. M. (1994). Taxonomic note: a place for DNA-DNA reassociation and $16 \mathrm{~S}$ rRNA sequence analysis in the present species definition in bacteriology. Int J Syst Bacteriol 44, 846-849.

Thompson, J. D., Gibson, T. J., Plewniak, F., Jeanmougin, F. \& Higgins, D. G. (1997). The CLUSTAL_X windows interface: flexible strategies for multiple sequence alignment aided by quality analysis tools. Nucleic Acids Res 25, 4876-4882. 